\title{
Para aprender e ensinar comunicação
}

MARQUES DE MELO, José. Midiologia para iniciantes - uma viagem coloquial ao planeta midia. Caxias do Sul: Educs, 2005, 1. ed. $211 \mathrm{p}$.

Marcel Proust, ao umedecer sua madeleine em uma xícara de chá, aciona um mecanismo de contato com momentos fundamentais de sua existência, das quais o leitor retira informações peculiares sobre a cultura de uma época. Abrir "Midiologia para iniciantes" e caminhar pelas entrevistas, diálogos e palestras que Marques de Melo nela reúne, é repetir o gesto proustiano na direção do planeta mídia. Conversas, reminiscências provocadas por uma série de interlocutores, desmistificam e renovam conceitos. Tais pressupostos, às vezes são enigmáticos para quem dá os primeiros passos no campo da comunicação social; outras preconceituosos, por causa do efeito colateral provocado pelo transplante de teorias construídas em e para realidades distintas, por quem já amadureceu na jovem academia brasileira.

Em linguagem humorada e descontraída, Marques de Melo vai compartilhando seus conhecimentos, sedimentados em mais de 30 anos de carreira acadêmica. Sobre mídia, por exemplo, ensina ser um vocábulo que chegou em terras nacionais por intermédio do Tio Sam, diretamente dos Estados Unidos, empacotada em Miami, legitimada em Washington e carimbada em Nova York. Avalia que estabelecemos com ela uma relação macunaímica, quase erótica, alterando-lhe o gênero e atribuindo-lhe sexo feminino. Popularíssima, com direito a verbete, corresponde a um sistema complexo de produção, circulação e consumo de bens culturais. Tal sistema é constituído por uma 
parafernália tecnológica movimentada pela indústria cultural, mas pertencente à esfera pública, apesar de funcionar sob gestão privada. O primeiro brasileiro a defender tese de doutorado em jornalismo apelida este sistema de esfinge, em livro recente ${ }^{1}$, e explica a metáfora a um de seus entrevistadores: na mitologia grega a esfinge de Tebas propunha enigmas aos viajantes. Hoje defrontamo-nos com situações idênticas, no cotidiano das vanguardas intelectuais, que se deparam com a esfinge midiática, desdenhando-a, sem elucidá-la cognitivamente, enquanto ela devora culturalmente nossa sociedade.

O fundador da Escola de Comunicação e Artes da USP indica, em várias passagens de sua midiologia, reconhecer a escassez de acúmulo sistematizado de conhecimento no país, e avalia que tal fato compromete a autonomia reflexiva nacional. Pondera que boa parte desta dependência se deve ao ambiente hostil cimentado pelas atitudes apocalípticas importadas d'além mar, que reprimem o desenvolvimento dos grupos de pesquisa brasileiros e latino-americanos, por cuja legitimidade ele vem se debatendo desde os anos 60 quando, jovem orientando de Luiz Beltrão, participou da criação do primeiro instituto de pesquisa acadêmica em comunicação no Brasil - o Icinform. Acrescenta dificuldades de financiamento e a incipiente cooperação internacional, entre outros fatores, à resistência já indicada, mas acredita tratar-se de um processo de amadurecimento, que será fortalecido pelas novas gerações de pesquisadores, "pois somente quando tivermos uma massa crítica consciente da identidade da nossa área de conhecimento, e capaz de argumentar de forma consistente no interior das agências de fomento, vamos superar as resistências que ainda persistem".

Como o autor indica, seus referentes cognitivos são enfeixados nesta obra, cujo índice é chamado de abecedário, porque aborda, de A até $\mathrm{Z}$, os temas predominantes neste ramo do conhecimento, aqui eleitos aleatoriamente. Discorre sobre as linhas de pesquisa predominantes nos estudos comunicacionais brasileiros, onde a variável política prepondera mas, conforme

1. A esfinge midiática. São Paulo: Paulus, 2004.

202 • Comunicação e Sociedade 45 
Marques de Melo, sob feição mais abstrata que operativa. Em sua opinião, "a reiteração de que a política é alma gêmea da comunicação pouco tem contribuído para melhorar a qualidade da comunicação pública, especialmente nas sociedades de desenvolvimento tardio (...)", um mero "contraponto em relação ao papel econômico ou mercadológico inerente ao funcionamento das indústrias midiáticas". Entende que "deveríamos contemplar, de modo incisivo, as demandas culturais (...) dos contingentes excluídos do usufruto do produto social (...) para quem a mídia funciona como escola paralela, disseminando valores e conhecimentos essenciais para a inserção no processo civilizatório".

Se útil para os aprendizes, o livro também é excelente auxiliar para professores que nele encontrarão textos para o ensino de temas como estudos de recepção, teorias do jornalismo das rotinas de trabalho até práticas de ensino, passando pela complexidade dos gêneros periodísticos, dos procedimentos editoriais e pela história da imprensa. Insere questões de natureza epistemológica, pronunciando-se a respeito do "tabuleiro cognitivo repleto de ambigüidades taxionômicas", que configura a midiologia brasileira, e apresenta as redes de pesquisa que lidera, na qualidade de diretor científico da Cátedra Unesco de Comunicação para o Desenvolvimento Regional. Finaliza com um "zum bibliográfico" e explica que as indicações de leitura são para complementar informações e ampliar conceitos tratados no livro.

Juçara Brittes

Professora do Departamento de Ciências da Informação da UFES Mestre e doutora em Ciências da Comunicação 